\title{
O NÁO-SER EM PARMÊNides de Eleia
}

\author{
Nicola Stefano Galgano ${ }^{1}$
}

Resumo: No fragmento DK 28 B 2 de seu poema, Parmênides apresenta seu método para distinguir a persuasão verdadeira da falta de persuasão verdadeira. As famosas duas vias para o pensar que ele propóe são o enunciado complexo de um sistema que quer garantir a veracidade das afirmaçôes para obter, afinal, um discurso confiável, o único capaz de persuasão verdadeira. O presente artigo mostra que o papel central da argumentação parmenidiana é atribuído ao não-ser, uma noção derivada certamente de uma reflexão sobre a impossibilidade da negação do ser. Assim, o inteiro fragmento é interpretado a partir dessa noçáo central, evidenciando que Parmênides descobre aquela impossibilidade de negação, que hoje nós chamamos de "contradição", e enuncia qual é a maneira de evitar a contradição no pensamento e no discurso, uma regra que atualmente nós chamamos princípio de náo-contradição. $\mathrm{O}$ estudo aqui apresentado faz uma investigação detalhada da noçâo de nấo-ser, no fragmento DK 28 B 2, oferecendo finalmente uma nova tradução.

Palavras-Chave: Parmênides. Não-ser. Não-contradição. Eleatismo. Parricídio.

\section{INTRODUÇão}

A expressão "não-ser", enquanto noção filosófica, comparece pela primeira vez com Parmênides. A história da filosofia mostra que "não-ser" não é uma noçáo trivial, como o uso pragmático que dela fazemos poderia sugerir. Desde seu aparecimento, no texto parmenidiano, o não-ser apresentou uma aporia fortíssima, talvez a maior das aporias, e, apesar das tentativas dos maiores filósofos, parece reapresentar-se de tempo em tempo, como uma ferida que se reabre, denunciando que, de fato, nunca cicatrizou. Da pragmática à noção crítica, o salto é tâo grande que, se se aplicasse à pragmática a noção crítica, o mundo, assim como nós pragmaticamente o vemos e interpretamos, cairia abaixo. O primeiro a perceber isso foi Parmênides e, com ele, os eleatas. A

\footnotetext{
${ }^{1}$ Pesquisador de Pós-Doutorado na USP, São Paulo, SP - Brasil. E-mail: nicolagalgano@usp.br
}

Entre os trabalhos recentes, destacam-se o livro I precetti della dea. Non essere e contraddizione in Parmenide di Elea (2017c) e a direçâoo geral do projeto internacional "Eleatic Ontology: origin and reception", para a publicaçáo, em múltiplos volumes, de uma obra sobre a influência do eleatismo em toda a história da filosofia.

http://dx.doi.org/10.1590/0101-3173.2018.v41n2.02.p9 
mais radical expressão da aporia eleática se encontra em Melisso. Com nossas palavras atuais, e com nossas noçóes, podemos expressá-la nestes termos: se, de um lado, não-ser é a negação absoluta do ser (não a negação do ser absoluto, mas a negação absoluta do ser), fica impossível sustentar a explicação comum do fenômeno que nós chamamos devir, o qual consiste em asserir que as coisas nascem e morrem, que tudo se transforma, que tudo passa a ser o que não era e deixa de ser o que era. A posta em jogo explicitada pela noção crítica de "não-ser" é simplesmente toda a estrutura da nossa visão de mundo. Por isso, constitui um problema genuinamente filosófico que absorveu as atençôes e os esforços dos grandes filósofos, ao longo da história do pensamento ocidental.

\section{O TEMA DO POEMA}

Os cerca de 160 versos do poema compóem atualmente 19 fragmentos, reconstruídos a partir de citaçóes. No primeiro fragmento, ao longo dos primeiros 27 versos, um cenário didático é apresentado: um jovem aprendiz (embora já preparado em sabedoria) é levado por um carro divino orientado por deusas, diante de uma deusa anônima, a qual será sua mestra de sabedoria e, até mesmo, eu diria com Cordero (1990), mestra de filosofia, se por filosofia entendemos a dedicação a qualquer saber, a todo o saber. Com efeito, logo na chegada do jovem aprendiz, depois das saudaçóes, a deusa apresenta o programa de aprendizagem, o primeiro autêntico índice programático (ROSSETTI, 2010) de que se tem notícia. Ela diz:
É necessário que tu aprendas tudo
tanto a mente firme que vem da verdade bem conexa
quanto a opiniáo dos mortais nos quais náo se encontra certeza verdadeira ${ }^{2}$ No entanto também isto aprenderás, como as aparências deviam validamente ser, tudo por tudo atravessando. ${ }^{3}$

Vamos desconsiderar aqui os últimos dois versos, os quais, além de ter tradução difícil e contestada reciprocamente nas muitas versôes dos vá-

\footnotetext{
${ }^{2}$ A justificação dessa tradução bastante diferente daquela proposta por Diels e por todos os demais críticos se encontra em Galgano (2012).

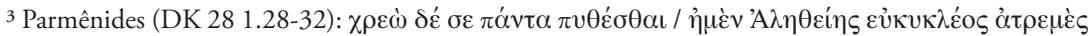

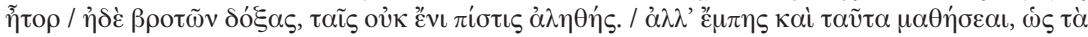

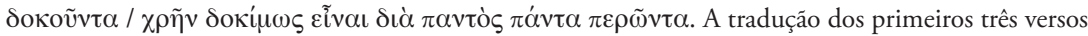
(1.28-30) é minha; a tradução dos últimos dois (1.31-2) é de Cavalcante de Souza (1978, p. 141).
} 
rios críticos, parecem referir-se à descrição do mundo dos fenômenos, parte do poema de que não trataremos aqui. Vamos examinar apenas os três versos anteriores. No primeiro, em sua segunda metade, a deusa anônima anuncia ao discípulo que ele irá aprender tudo $(\pi \alpha ́ v \tau \alpha)^{4}$ : tanto a mente firme, fruto da verdade bem conexa, quanto as opinióes dos mortais, onde as certezas não são verdadeiras. As duas afirmaçôes são precedidas pelas

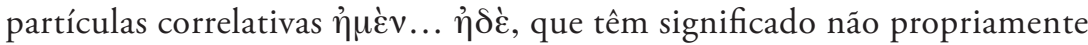
adversativo, mas antitético (SMYTH, 1956, p. 644) e têm como tradução "de fato, por um lado ... de fato, por outro lado." (DENNISTON, 1954, p. 287). A antítese se refere a dois tipos de estados cognitivos antitéticos, cada um com sua respectiva qualificação: por um lado, a mente firme, resultado da verdade bem conexa; por outro lado, as opinióes dos mortais, que aqui não significam um conjunto de conhecimentos, mas uma maneira de pensar, a qual não possui uma certeza verdadeira. Se consideramos a estrutura antitética, podemos ver que a mente firme é antítese de "opiniáo dos mortais", enquanto "verdade bem conexa" está em antítese com "falta de certeza verdadeira”. O que Parmênides traz em questão é aproximadamente aquilo que hoje chamaríamos de criteriologia, ou seja, o estudo daquilo que faz com que uma proposição possa ser tida como verdadeira. Ele o faz à sua maneira, arcaica, sem uma terminologia pronta disponível e com pouquíssimo questionamento já culturalmente assentado sobre esse tema. Grosso modo, tradicionalmente se entendia, com as devidas exceçôes, que os deuses falavam a verdade, de forma que o relato mítico, embora pudesse até parecer inverossímil, era tido por verdadeiro (como atualmente ainda acontece com muitos livros considerados sagrados pelas religióes atuais). Todavia, uma crítica ferrenha aos relatos míticos e aos cultos religiosos já estava em ato no pensamento dos jônicos ${ }^{5}$, e Parmênides outra coisa não faz senão dar um passo à frente, nesse caminho.

A visão crítica de Parmênides é primorosa. De fato, ele póe em evidência, a partir da constatação de que há "verdades” não verdadeiras (Xenófanes),

${ }^{4} \mathrm{O}$ programa de aprendizagem oferecido por Parmênides, por ser o mais avançado da época, tem como público-alvo pessoas já de elevada cultura.

5 Por exemplo, Xenófanes: em DK 21 B 14, "Mas os mortais acreditam que os deuses são gerados, / que como eles se vestem e têm voz e corpo."; em DK 21 B 15, "Mas se mãos tivessem os bois, os cavalos e os leôes / e pudessem com as mãos desenhar e criar obras como os homens, / os cavalos semelhantes aos cavalos, os bois semelhantes aos bois, / desenhariam as formas dos deuses e os corpos fariam / tais quais eles próprios têm."; e em DK 21 B 16, "Os egípcios dizem que os deuses têm nariz chato e são negros, / os trácios, que eles têm olhos verdes e cabelos ruivos." (CAVALCANTE DE SOUZA, 1978, tradução de A. L. Prado). 
que aquilo que é chamado de "verdade" (relato verdadeiro, na concepção arcaica da noção da verdade) é antes de tudo um fato psicológico subjetivo, é uma convicção, uma certeza subjetiva, um "estar persuadido de". Dada essa convicção, do ponto de vista subjetivo, ela é sempre uma verdade, mas olhando as coisas de fora, é possível perceber que há convicções que não são verdadeiras (exemplo, as várias concepçóes míticas a respeito do todo ou dos deuses). Desse modo, a convicção subjetiva passa a não ser mais critério suficiente de verdade: é necessário um método que garanta à mente a certeza da convicção, agora colocada em dúvida pela observação do comportamento cognitivo das várias culturas (Xenófanes). Em outras palavras, uma vez observado que a convicção subjetiva não é suficiente para garantir a veracidade daquela proposição, é necessário encontrar um outro método que garanta essa veracidade. ${ }^{6}$

Observemos, pois, o status questionis proposto por Parmênides: (1) a mente em geral tem convicçôes ${ }^{7}$; (2) porém, agora sabemos que estar convencido de algo não é suficiente para garantir a verdade daquela convicção, logo, não sabemos se as convicçôes da mente são verdadeiras ou não; (3) há um método objetivo que garante a verdade das convicçôes (que são sempre subjetivas); (4) depois da aplicação do método, sabemos que há convicções verdadeiras e convicçóes não verdadeiras: as primeiras deixam a mente firme e sem a oscilação da dúvida, as segundas são aquelas que, submetidas ao método, deixam a mente em oscilação (são as opiniōes dos mortais). Podemos, assim, reler a expressão da deusa: "É necessário que tu aprendas (a respeito do) 'tudo', por um lado, a mente firme que vem da verdade bem conexa

${ }^{6}$ Que Parmênides, em sua crítica, esteja referindo-se ao pensamento tradicional pode ser inferido pelo todo do poema. Mas há passagens, aqui não discutidas, as quais evidenciam essa crítica. $\mathrm{O}$ elemento mais importante, parece-me, é que ele se refere aos brotoi, os mortais, os quais têm opinióes (crenças nos relatos míticos, especificamente aqueles voltados a explicar os fatos naturais) nas quais falta a certeza confiável. Quem são os brotoi? Embora haja divergências e alguns queiram ver nos brotoi figuras relacionadas a pensadores supostamente antagonistas (por exemplo, os heraclitianos), há uma passagem que nos faz entender claramente que se trata de uma crítica ao pensamento mítico tradicional. No fr. 7 , a deusa convida o discípulo a não permitir que um ethos polypeirov, o hábito de muita experiência, o obrigue a permanecer no caminho errado. O que é ethos polypeirov? Trata-se de um hábito de pensamento que se adquire pela repetida experiência (cultural). Um tal hábito, por razóes cronológicas, não pode ser proveniente da forma mentis própria das recentes conquistas da ciência jônica, ou daquela pitagórica; recentes demais para chegar a serem consideradas uma maneira de pensar assentada, isto é, um ethos polypeiron, um hábito de muita experiência. Afora essas correntes, não há outros candidatos de pensamento "não mítico" que podem ser alvo da crítica de Parmênides. Por conseguinte, como objeto das críticas, resta somente o pensamento mítico tradicional, isto é, aqueles relatos que, de uma maneira ou de outra, tentavam explicar o mundo, o que coloca Parmênides em perfeita continuidade com seu mestre Xenófanes.

7 Para a noção de "mente”, em Parmênides, ver Galgano (2016, 2017), parte primeira e segunda. 
(aquela que passou pelo método) e, por outro, as opiniōes dos mortais, nas quais a convicção não é verificada.”

\section{Os CAMINHos}

Após a explicitação do programa de ensino, a deusa começa a explicar seu método de verificação. É aqui que nos deteremos mais, porque é neste ponto que estreia pela primeira vez a noção de não-ser. Trata-se do fr. DK 28 B 2, que ora passamos a estudar e que em grego é assim:

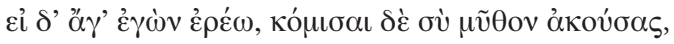

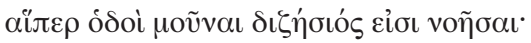

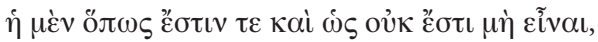

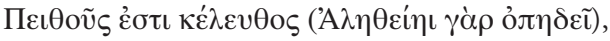

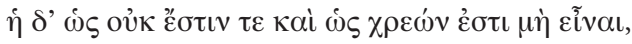

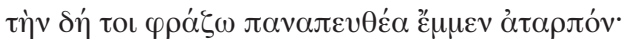

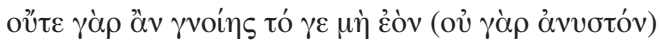

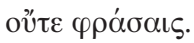

\subsection{Os Versos 1 E 2}

Vejamos os primeiros dois versos do fragmento:

Ei d'ág'egòn eréó, kómisai dè sù mụ̂thon akoúsas háiper hodoì moûnai dizésios eisi noôsai;

Pois bem, en te direi, e tu recebe a palavra que ouviste, os únicos caminhos de inquérito que são a pensar;

Sua importância é estrutural dentro do poema: a deusa anuncia que vai dizer algo importante e pede ao kouros para preparar-se, pois há caminhos específicos para o pensar investigativo e são somente alguns (moûnai, depois saberemos que são dois).

Houve muita discussão sobre o sentido de voñoal, principalmente sobre se ele é ativo ou passivo. Aqui, noesai se refere a um pensar investigativo, o 
qual é necessariamente ativo, pois uma investigação passiva é um dos oximoros mais esdrúxulos imagináveis. O sentido é: os caminhos que o pensar segue, quando se dedica à investigação, são aqueles únicos que descreverá a seguir. Uma outra maneira de traduzir pode ser esta: o pensar, entre todos os caminhos possíveis, segue estes únicos, em sua atividade de investigar. Portanto, a tradução de Cavalcante de Souza soa ótima, a pensar... que.

Vejamos, na sequência, a coordenação com os versos 3 e 5, que apresentam os correlativos, começando pela construção:

Pois bem, eu te direi, e tu recebe a palavra que ouviste,

que os únicos caminhos de inquérito são:

(verso 2 + verso 3) a pensar que é, e que, portanto, não é não ser;

(verso $2+$ verso 5) a pensar que náo é, e, portanto, que é preciso não ser.

A construção mostra que o sentido do noein (voñoal), nesse caso, é ativo. Há uma atividade específica da mente. Nessa atividade, a mente se encaminha por vários rumos de investigação, dos quais somente dois parecem ser viáveis, ou parecem ter sentido: a investigação a pensar que é; e a investigação a pensar que não é.

Que nos diz esse verso 2? Que Parmênides se pôs a refletir sobre a mente humana, embora ele não tivesse esse conceito de "mente", como nós a entendemos. Essa reflexão foi fatal e, aos poucos, veremos por quê. Por enquanto, podemos sustentar que o ponto de partida de Parmênides é reflexivo. Sua reflexão verteu sobre o funcionamento da mente, mais especificamente sobre que tipo de funcionamento leva à persuasão ou leva a conclusôes insatisfatórias, do ponto de vista da explicação do mundo.

\subsection{OS VERSOS 3 E 4}

he mèn hópọs éstin te kaì ôs ésti mè eînai, peithoûs esti kéleuthos (alętheíei gàr opedeî),

o primeiro, que é e, portanto, que não é não-ser, de persuasão é o caminho (pois à verdade acompanha), 
O verso 3 é provavelmente o mais estudado de Parmênides: merece. Entretanto, vejamos primeiro o verso 4. Ali notamos a presença de uma palavra marcadamente psicológica, $\pi \varepsilon \imath \theta 0 \tilde{v} \varsigma$, persuasão. Parmênides percebe que a persuasão é um fato da "mente", conceito este último que lhe é estranho, mas que ele consegue identificar, descrevendo as sensaçôes mentais. ${ }^{8} \mathrm{E}$ identifica duas persuasôes: uma acompanhada da verdade e outra na qual o convencimento não é acompanhado da verdadeira confiança. À primeira, ele chama de $\pi \varepsilon \iota \theta$ ó $\varsigma$, que gera a sensação de firmeza na mente ( $\alpha \dot{\tau} \rho \varepsilon \mu \dot{\varepsilon} \varsigma \tilde{\eta} \tau o \rho$, DK 1. 29) e acompanha a verdade. À segunda, ele chama de "opiniōes dos

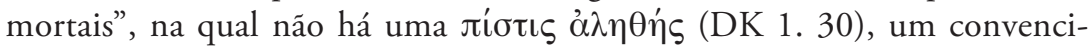
mento acompanhado de verdade.

Essa distinção nos mostra agudeza da observação psicológica. A certeza pode ser de dois tipos: ou é uma certeza que deixa espaço a dúvidas ou é uma certeza indubitável. Isso expóe um problema gnosiológico: posto que se tem uma convicção (e todo homem tem convicçôes), como saber se essa convicção corresponde à verdade ou é uma convicção sem fundamento e sem correspondência com a realidade? Não é possível sabê-lo. A mente mostra apenas sua convicção subjetiva e, para saber se tal convicção é acompanhada de verdade ou se não tem fé verdadeira, é preciso recorrer a algo extramental, é necessária uma prova externa, porque a mente por si só náo consegue identificar uma sua convicção própria como verdadeira ou falsa.

A diferenciação de dois tipos de persuasão no poema é clara9 e, se a ordem dos fragmentos de Diels estiver correta, essa diferenciação pertence à parte propedêutica, pois não se fala dela na parte do eon, no fr. 8 , quando a ordem do mundo é explicada, com exceção do final do discurso da deusa, onde ela anuncia o encerramento de seu discurso confiável ( $\pi \iota \sigma \tau o ̀ v ~ \lambda o ́ \gamma o v$ ). Isso significa que esse tema faz parte do instrumental argumentativo prévio que conduzirá à sucessiva análise cosmológica. Enfim, nos versos 3-4, uma proclamação anteriormente anunciada (vv. 1-2) é agora enunciada (vv. 3-4), em seu primeiro caminho. É enunciado o caminho que pensa o inquérito com persuasão verdadeira, não aquele pensar no qual não há convicção ver-

\footnotetext{
${ }^{8}$ A discussão completa está em Galgano (2012).

9 Embora, nesse fragmento, a palavra persuasão não apareça associada aos "mortais", em outras partes, essa ligação é clara ou até mesmo literal, como em 8. 38-39, onde se frisa que "serão nomes todas as

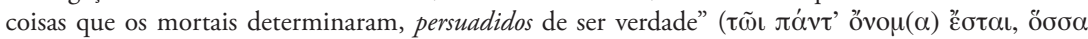

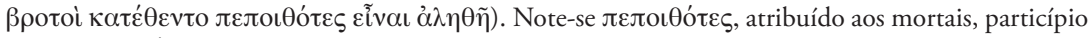
perfeito de $\pi \varepsilon i \theta \omega$.
} 
dadeira, mas aquele caminho, enfim, que anda com a verdade. Vamos agora voltar ao verso 3 .

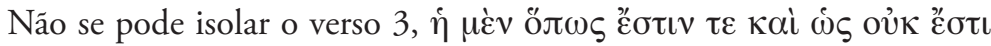

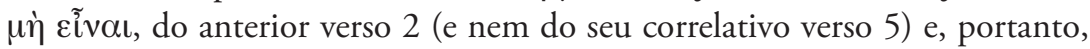
náo se pode esquecer que trata de um caminho, ou seja, de um elemento dinâmico. No entanto, a primeira coisa que salta aos olhos é que todas as noções envolvidas são estáticas e não há nenhum elemento dinâmico ou sequencial ou de qualquer natureza minimamente motora. O sentido, desse ponto de vista,

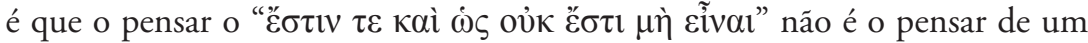
momento, mas um pensar que segue por um caminho. Ou seja, significa que, no percurso seguido pelo pensar, para que o inquérito seja de verdadeira per-

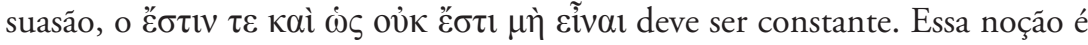
estrutural: o caminho de inquérito a pensar deve conter uma constante, válida em qualquer momento e passagem do caminho. $O$ fato de ser a afirmação de uma constante (estática), numa dimensão de caminho (dinâmica), reforça a ideia de algo externo e de natureza fixa, a ser aplicado a algo de natureza processual, ou seja, é uma lei, porque a noção de lei expressa também as relaçôes fixas entre as dinâmicas de elementos de um ou mais processos.

Vamos observar a estrutura sintática do verso mais de perto: $\dot{\eta} \mu \dot{\varepsilon} v$

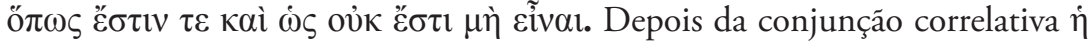
$\mu \grave{\varepsilon} v$ - que se coadunará com o $\dot{\eta} \delta \grave{\varepsilon}$ de 2.5 ( $\dot{\eta} \delta$ ' $\dot{\omega} \varsigma$ ) - o verso é constituído de duas unidades sintáticas autônomas, mas subordinadas ao verso 2 pelos pronomes ő $\pi \omega \varsigma$ e $\omega \varsigma$, ademais as duas unidades estão ligadas pela conjunção $\tau \varepsilon$ אaì. Vejamos a construção sintática, sem entrar ainda na semântica, ou seja,

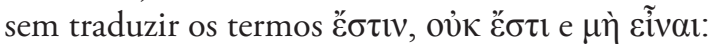

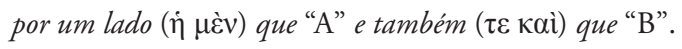

A conjunção $\tau \varepsilon$ кaì (e também que) indica que temos duas orações, as quais, pela estrutura de todo o fragmento, devem ser completas. Devem, porque não parece que o sejam; vejamo-las separadamente e sem os pronomes:
A. ह̌ $\sigma \tau \imath$;

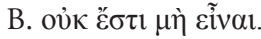

A primeira oração é sem sujeito e sem objeto, sendo constituída somente pelo verbo; a segunda é igualmente sem sujeito, contudo, tem um objeto 
direto. A primeira é afirmativa, enquanto a segunda é negativa; entretanto, a segunda nega uma segunda negação contida no objeto, é negação de negação.

\begin{tabular}{|c|c|c|c|c|c|c|}
\hline & & $\begin{array}{l}\text { Conjunçáo } \\
\text { correlativa }\end{array}$ & $\begin{array}{c}\text { Pronome } \\
\text { relativo }\end{array}$ & sujeito & verbo & objeto \\
\hline Verso 2.3 & & $\dot{\eta} \mu \bar{\varepsilon} \nu$ & & & & \\
\hline & Oração 1 & & $0 ̈ \pi \omega \varsigma$ & - & $\varepsilon \check{\varepsilon} \sigma \tau t \nu$ & - \\
\hline & Oração 2 & & $\dot{\omega} \varsigma$ & - & 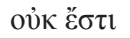 & 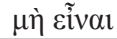 \\
\hline
\end{tabular}

Posto que em grego antigo o sujeito ou é explícito ou é subentendido, o grande mistério dessas palavras é exatamente que o sujeito não aparece, nem explícito e nem subentendido, constituindo uma autêntica anomalia literária. Não convém, nesta ocasião, reconstruir a discussão dos vários estudiosos em relação a essa falta; de nosso lado, enfrentaremos a questão por outras providências. Por enquanto, vamos apresentar o resumo das possibilidades de solução reportadas por Cordero (2005). Para o estudioso, há quatro possibilidades para explicar a anomalia, a saber: "a) Trata-se de um erro de transmissão de texto; se assim for, este deve ser corrigido introduzindo o sujeito ausente; b) há um sujeito conceitual implícito que deve ser buscado no resto do Poema; c) não há nenhum sujeito possível; e d) o sujeito deve ser extraído do predicado isolado, pois o éstin "produz" o sujeito. As quatro possibilidades encontraram defensores." (CORDERO, 2005, p. 63).

Não penso que seja o caso de tomar partido agora; faremos isso somente no fim da nossa análise; por enquanto, vamos prosseguir com as nossas consideraçôes. A primeira delas é que as duas oraçóes não são simplesmente conjuntas, elas são mais que conjuntas porque reúnem uma única

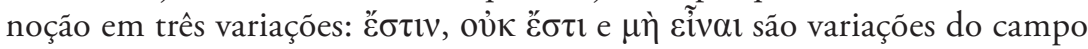
semântico de عỉuí, o verbo ser. Seriam simplesmente conjuntas, se apresentassem verbos e objetos diretos diferentes. Naturalmente, uma construção desse tipo seria possível ${ }^{10}$ e apresentaria duas oraçóes sintaticamente independentes e conjuntas. Porém, no nosso caso, a construção é feita com três formas do mesmo verbo, que muito dificilmente têm uma conexão apenas conjuntiva. Ademais, a primeira oração é afirmativa e a segunda duplamente negativa, o que faz pensar na estrutura da citação platônica (Soph. 237a8; DK B 7. 1), a qual não é sintaticamente igual, mas muito semelhante: que nunca os não entes sejam, onde também uma dupla negação recusa existência

${ }^{10}$ Por exemplo: "os únicos caminhos de inquérito a pensar, por um lado, que examina e que não pretende nâo avaliar..." 
aos não entes, implicando apenas variaçôes formais de cĩv $\alpha$, dessa vez com o particípio no neutro plural, $\tau$ ò غ̇ov $\tau \alpha$, que não está presente no fr. $2 .{ }^{11}$ Esses elementos precisam ser investigados.

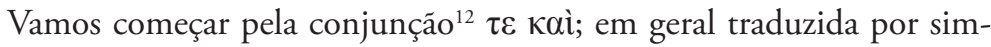
ples conjunção pelos críticos, assume aqui um valor mais forte. $\mathrm{O}$ fato de que seja uma conjunção elimina, de início, a interpretação do verso 3 como uma disjunção. ${ }^{13}$ Mais que uma conjunção, as duas subordinadas são ligadas por

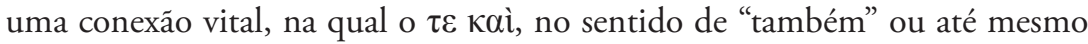
"ambos", representa a conjunção de uma segunda parte reforçando a primeira, não porque explica, mas simplesmente porque as duas fazem parte de um todo, como dois lados de uma mesma moeda. ${ }^{14}$

Vamos deixar de lado, por enquanto, o primeiro hemistíquio e considerar somente o segundo. O segundo hemistíquio de 3 soa assim: os únicos caminhos de inquérito a pensar são, por um lado que ["A"] e também que não é não-ser. O fato singular é que, além da repetição da negação (não... nãa), tem-se também a repetição do verbo eỉní (é... ser). Obviamente, não se trata de uma ditografia e, portanto, teremos que diferenciar o primeiro negar

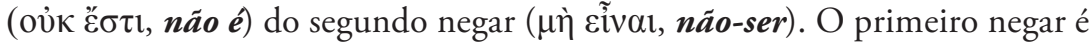

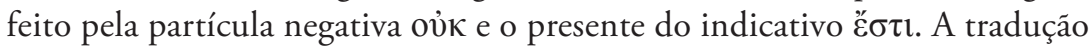
simples e direta soa: não é. Náo parece haver dificuldade quanto à tradução em si, restando apenas o problema da falta de sujeito. Se "não é" está certo, resta descobrir a que se refere essa negação, e não há outro candidato que o seguinte $\mu \grave{\eta}$ घĩvat.

\footnotetext{
${ }^{11}$ É possível mostrar (e o fazemos em sede apropriada) que a citação platônica (v. 7. 2) tem a mesma estrutura do v. 2. 3 .

${ }^{12}$ Humbert (1954, p. 370): “D’ailleurs, d’une façon générale une certaine indétermination, inséparable de la poésie qui exprime moins qu'elle ne suggère, est peu favorable à un emploi rigoreux et précis des particules."

${ }^{13}$ Alguns interpretam de fato como disjunção, ex. Mansfeld (1960), em Meijer (1997), p. 100 et passim. $\mathrm{O}$ argumento de Mansfeld parte da consideraçáo de que o silogismo disjuntivo não precisa

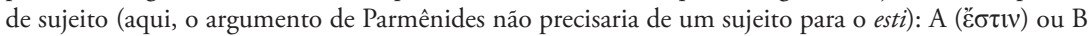

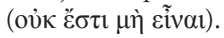

${ }^{14}$ Aparentemente (pelo que pude descobrir), não há estudos atuais completos sobre as partículas em grego antigo, e parece que o último foi de Denniston (1954). De lá para cá, as partículas foram estudadas por trabalhos específicos e separadamente por áreas literárias (épica, tragédia etc.), deixando uma lacuna na poesia, onde o uso é muito menos rigoroso e oferece maiores dificuldades de interpretação. Um status questionis da problemática de te kai possivelmente se encontra em um paper do qual, por enquanto, só consegui o abstract: Bonifazi (2012).
} 
Não parece haver atestação de $\mu$ ̀̀ घĩv $\alpha$ l, na poesia épica. Pela pesquisa no TLG, as primeiras atestaçôes parecem ser da época de Parmênides, se não sucessivas, sendo que, nesse caso, pode ter sido ele o primeiro a usar tal expressão. Mas, aguardando resultados filológicos mais precisos, podemos assegurar que a noção de عĩval, contida no segundo negar, não deve ser a mesma do primeiro, sob pena de gerar uma contradição de termos incompreensível, mas que, justamente nesse sentido, atiçou a fantasia de muitos críticos. Penso, por exemplo, naqueles que quiseram ver as duas negaçóes apenas no sentido gramatical ${ }^{15}$ e acabaram achando o argumento de Parmênides fraco ou tautológi-

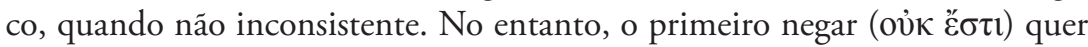
negar um outro negar $(\mu \grave{)})$ específico, aquele que nega cĩval.

Vou repetir a sequência porque, por um lado, a ação do primeiro negar é predicativa e, por outro lado, a noção predicada é máxima e acaba por gerar um pequeno desconforto argumentativo. $\mathrm{O}$ primeiro negar nega um segundo negar, aquele que nega eĩval. Ou seja, o segundo negar é um "negar algo espe-

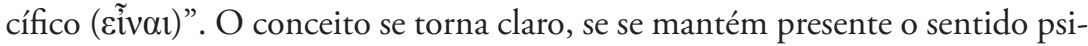
cológico, muito mais que o gnosiológico, da expressão parmenidiana. Negar algo é o que fazem ambas as expressóes, tanto do primeiro quanto do segundo negar. Todavia, o segundo negar é a ação específica de negação de Ẽ̃val, a qual é uma ação da mente, é um comportamento concreto, o comportamento mental de negar cĩval. Parmênides argumenta que o caminho persuasivo é aquele que nega que se possa ter o comportamento mental específico de negar Eĩval: não é possível (ter o comportamento mental de) negar Ẽ̃val.

Esse é um ponto que gerou muita confusão. Parmênides não nega que se possa negar, como se ele próprio, ao afirmar que o não-ser não é, estivesse cometendo o maior dos disparates autocontraditórios. São muitíssimos os que interpretam Parmênides dessa forma e que, afinal, acabam asseverando que Parmênides é o filosofo do ser (apenas). Parmênides usa gramaticalmente a negação, e também a usa gnosiologicamente e epistemicamente. Dá para dizer mais: dá para dizer que ele usa a negação de forma magistral, como poucos souberam usar na história da filosofia. De fato, o segundo hemistíquio assevera que há um percurso mental que é persuasivo (v. 4), quando não segue $\mu$ ì घĩval. Mais uma vez: o percurso mental de inquérito é persuasivo, quando não

${ }^{15}$ Por exemplo, C. Kahn, cuja única conclusão, segundo sua leitura, seria: "If we restate Parmenides' claim in the modern, formal mode, it might run: 'm knows that p' entails 'p'." (KAHN, 2009, p. 153-154). 
se comporta mentalmente, negando عĩvol, quando não tem a atitude de negar

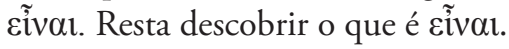

O termo عĩvaı é um infinitivo. Como se sabe, o infinitivo é a expressão verbal depauperada de todo sentido acessório, a ponto que "[c]'est de cette façon négative que l'infinitif a été défini comme représentant l'idée verbale nue." (HUMBERT, 1954, p. 125). Os mais variados estudos não conseguiram explicar de forma convincente um sentido específico para o uso feito por Parmênides. Por exemplo, The verb "be" in ancient Greek (KAHN, 2003, passim), um dos estudos mais completos sobre o tema, vê-se obrigado a atribuir a Parmênides um uso supostamente novo, mas, parece-me, de forma imprópria e desnecessária. ${ }^{16}$ Eu penso que, quando Parmênides quis utilizar um novo sentido, inventou um novo termo, como no caso de to eon (invenção na linha já consolidada de substantivar verbos no gênero neutro). Não fez o mesmo com દĩvol e suas demais formas verbais, razão pela qual o sentido deve ser buscado nas acepções tradicionais, as quais são múltiplas e equívocas, como dirá mais tarde Aristóteles.

No infinitivo, عĩval expressa a ideia geral do verbo, num campo semântico que vai desde "presença" até a função predicativa comum a muitas línguas indo-europeias. Creio que seja inútil buscar um sentido preciso, como "existir" ou "estar presente localmente" ou outro. Eĩval significa tudo isso, principalmente porque é usado no infinitivo e como objeto. Em português, a palavra que expressa com a mesma equivocidade a pluralidade de sentido numa riqueza próxima ao grego, é o verbo "ser". ${ }^{17}$ Parece-me, portanto, perfeitamente inútil cercear o sentido a uma única acepção, restrição que acaba gerando interpretações polêmicas. Até mesmo para a acepção de "existir" se construíram críticas, a meu ver, impróprias, pelas quais se chega a discutir se Parmênides pensasse ou não que seres não existentes como quimeras e outros

\footnotetext{
${ }^{16}$ Kahn extrai o sentido de cĩval em Parmênides não do uso que o eleata faz, mas do contexto geral da mensagem parmenidiana. Teoricamente, seria um método viável, posto que se consiga entender corretamente a mensagem do filósofo. Na prática, no caso do poema de Parmênides, que verte exatamente sobre عĩval e seus derivados, há um risco enorme - ao qual, em minha visão, Kahn sucumbiu - de cair num petitio principii, onde o sentido de cĩval é extraído da mensagem filosófica geral (Kahn o extrai de 1.29, que é o "índice parmenidiano" e, portanto, poderia oferecer a ideia geral do poema) e, por sua vez, a mensagem filosófica é obtida a partir do sentido de eĩval. Kahn acredita ter encontrado no sentido "veritativo" o novo uso que Parmênides faz de cĩvou.

${ }^{17}$ Para Eỉú́, o Dicionário LSJ apresenta sete campos (de A a G) com 16 acepções e mais várias subacepçôes. Para o verbo "ser", o Dicionário Houaiss apresenta 19 acepçôes, das quais 14 verbais e 5 como substantivo; as subacepçóes são exemplificadas, mas não classificadas.
} 
seres mitológicos pudessem ser incluídos na leitura predicamental. ${ }^{18}$ Principalmente, é necessário manter a equivocidade do termo, porque corresponde à forma mentis do autor e não se devem exigir distinçôes que não eram processadas por aquela cultura, sob pena, mais uma vez, de atribuir aos antigos a nossa própria forma mentis, pecado fatal para um historiador da filosofia.

Desse modo, de início, a tradução de $\mu$ ì cĩvaı com "não-ser", até mesmo por ser equívoca (para a nossa sensibilidade), mantém a equivocidade própria da época e da língua da época. Posta, então, essa equivocidade, precisamos saber se expressa um sentido filosófico, antes de tudo para a época e depois

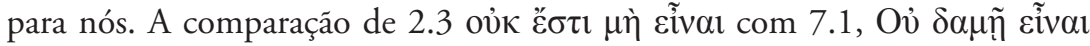

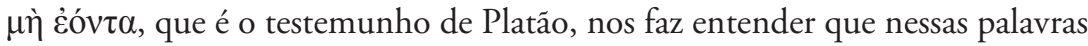
não só se encontra um sentido filosófico, mas até mesmo o sentido principal da filosofia de Parmênides. Retomando, portanto, a construçáo, precisamos

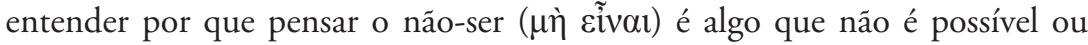
que não se deve fazer ou que simplesmente não é (não acontece), segundo a

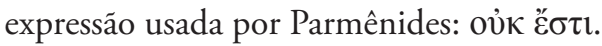

Além da tradução simples e imediata, haveria outras possibilidades de tradução ${ }^{19}$; essas variaçóes podem ser interessantes para evidenciar nuances aqui e acolá, contudo, tendo a possibilidade de utilizar o verbo "ser" num uso equívoco próximo do grego, não precisamos recorrer à circunlocuções e pode-

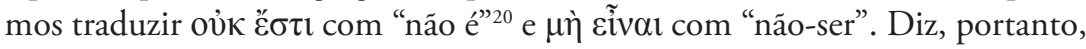
o segundo hemistíquio:

\section{Os únicos caminhos de inquérito ao pensar são}

Por um lado ["A"] e que não é náo-ser.

\footnotetext{
${ }^{18}$ De novo, Kahn (2009), que assinala: "To take the philosophical objection first: it is simply false to say that you cannot think or talk about (point out in speech, phrazein) what does not exist. And the falseness of this would be obvious to any Greek who reflected for a moment on the profusion of monsters and fantastic creatures in traditional poetry and myth, from Pegasus to the children of Gaia with a hundred arms and fifty heads apiece." (HESIOD, THEOGONY, 150, 172). Mais à frente, ressaltamos que, exatamente na questão filosófica, Kahn está errado e Parmênides está certo: é impossível pensar e dizer o não-ser.

${ }^{19}$ Um outro caminho possível de tradução, utilizado principalmente pelos autores de língua inglesa, por motivos idiossincrásicos da língua, é empregar uma expressão cuja noção também é amplíssima e equívoca: "coisa". Mas essa expressão, por ser um substantivo, não possui o aspecto dinâmico que o verbo tem, sendo assim necessário acrescentar o verbo ser; portanto, é possível traduzir com "as coisas que são". Outra possibilidade é usar o pronome "que”, em sentido predicativo, em substituição de coisa ou coisas. Outra ainda é o pronome demonstrativo (aquilo, isto) ou o indefinido (algo), com a mesma função substitutiva de coisa(s), no sentido mais indefinido possível.
}

${ }^{20}$ Lá onde, em inglês, há obrigatoriedade de explicitar-se o sujeito: "what is not". 
Se tivéssemos seguido a ordem metodológica tradicional, ao examinar

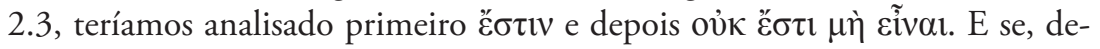
pois de estudar o segundo hemistíquio, voltássemos nossa atenção ao primeiro hemistíquio, não teríamos ganho metodológico nenhum, pois redundaríamos

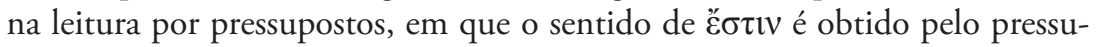
posto de que ع̌ $\sigma \tau \imath v$ significa, em grego, "ê"; todavia, dessa maneira se chegaria aos resultados já conhecidos, considerados não totalmente satisfatórios pelos próprios autores de cada interpretação. $\mathrm{O}$ dado concreto é que o poema não oferece nenhuma definição direta ou indireta de $\check{\sigma} \sigma \tau \imath v$, embora apresente mui-

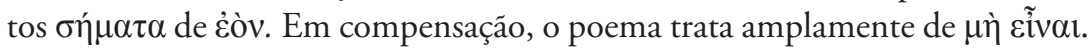
E não é preciso ir muito longe para encontrar referências para a noção de $\mu \grave{\eta}$ Eivval, pois observamos muitos dados nos versos de 5 a 8 , do nosso fragmento. Iremos, portanto, ao verso 5 e subsequentes.

\subsection{Os Versos 5 a 8}

hẹ d'os ouk éstin te kaì os khreón esti mè eînai,
tèn dé toi phrázo panapeuthéa émmen atarpón;
oúte gàr àv gnoíés tó ge mè eòn (ou gàr anustón)
oúte phrázais

o outro, que não é e, portanto, que é preciso não ser, este então, eu te digo, é atalho de todo incrivel; pois nem conhecerias o que não é (pois não é exequivel), nem o dirias...

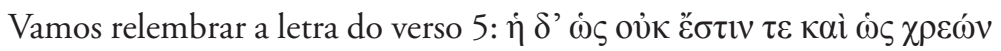

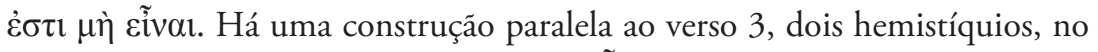

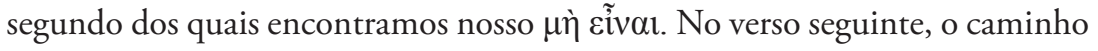
é chamado de $\pi \alpha v \alpha \pi \varepsilon v \theta \varepsilon \dot{\varepsilon} \alpha$, termo que muito fez e faz sofrer os filólogos. O sentido geral, porém, é claro, quer se queira traduzir como "de todo incrível" (CAVALCANTE DE SOUZA, 1978), quer como "completamente inconoscible" (CORDERO, 2005, p. 219), ou "wholly without report" (COXON, 2009, p. 56), ou como outro. Em suma, a noção geral é de que há uma dificuldade intransponível em seguir esse caminho e por que é explicado a seguir. 
Assim como em certa metodologia de exposição, primeiro se enuncia a tese e depois se propóe o argumento demonstrativo, Parmênides primeiro enuncia (como convém à expressão de uma deusa) e depois diz por quê. Ora, a novidade cultural é exatamente esse porquê, onde as afirmações não são mais apenas impostas por sua força hierática, mas precisam de explicaçôes. ${ }^{21}$

O nosso primeiro problema é que os enunciados (no verso 3, antes, no verso 5, agora) não são claros para nós. Nesse sentido, podemos pedir clareza

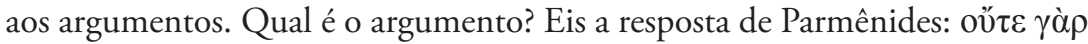

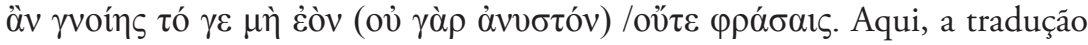
é mais clara e não há muita divergência entre os críticos: pois nem poderias conhecer o que não é (pois é impossivel), nem o dirias. Há aqui um claro objeto do discurso, $\tau$ ó $\mu$ ̀̀ èòv, o qual, sem hesitaçáo, desta vez, podemos traduzir por "o que não é”. Sem hesitação, porque tò ċòv é uma expressão desconhecida antes de Parmênides: aparece com ele, é estudada por seus discípulos e pelos seus críticos (de Melisso a Aristóteles) e é reportada pela doxografia como invenção parmenidiana.

A noção exposta por Parmênides é sequencial: o caminho de inquérito

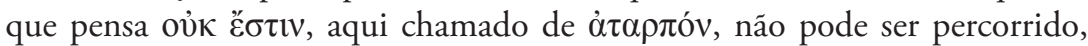
porque é impossível "conhecer" ( $\gamma$ voín - segunda pessoa do optativo aoristo ativo de $\gamma(\gamma \vee \omega ́ \sigma \kappa \omega)$ o que não é; e vamos deixar para depois a questáo do di-

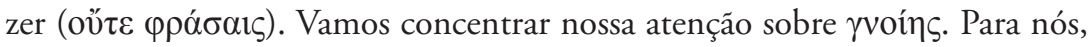
é menos importante a tradução gramaticalmente e estilisticamente precisa e mais importante a precisão da noção filosófica exposta. Em relação a essa palavra, houve (e ainda há) uma discussão acirrada. Discute-se se traduzir por "conhecer", como fazem alguns (COXON, 2009, p. 56; GALLOP, 1984, p. 55; TARÁN, 1965, p. 32, e muitos outros), ou "reconhecer" como fazem outros (por exemplo, BARNES, 1982, p. 124) e, principalmente, que sentido atribuir ao "conhecer". Eu penso que, considerado o contexto, não se trata do conhecer epistêmico, mas do conhecer gnosiológico, ou seja, da capacidade que a mente possui de estabelecer um processo de conhecimento. E que se trate de processo é claro, pela vária terminologia que Parmênides usa, mas principalmente pela sua ó ós, que ficará para sempre como metáfora perfeita dos procedimentos a serem tomados para realizar tarefas de qualquer natureza, vindo a receber o nome de método.

\footnotetext{
${ }^{21}$ Rossetti (2010). A necessidade de explicaçôes não é mais só dos autores, mas também da audiência, que agora requer argumentos.
} 
Para o método do pensar epistêmico, declara Parmênides, não é conveniente seguir um certo percurso, porque sobre ele há ao menos uma etapa onde se deve "conhecer" - ou seja, onde se deve exercer a capacidade gnosioló-

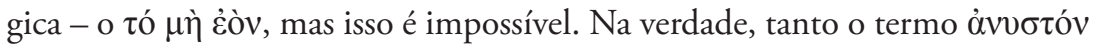

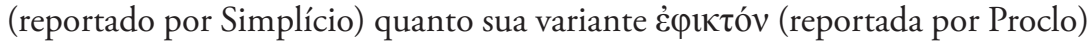

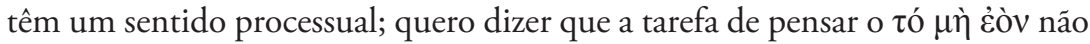
apresenta uma impossibilidade que se realiza imediatamente, mas uma que implica um processo, o qual é impossível em sua inteireza, porque náo pode

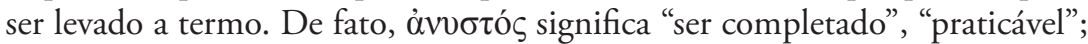

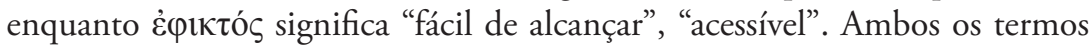
têm sentido dinâmico e processual, e a negação que Parmênides faz significa que esse processo não pode ser levado a termo.

De que processo se trata? Em minha visão, trata-se do processo concreto de pensar a negação do ser. Parmênides é de área de formação pitagórica, e os pitagóricos - como assinala Aristóteles (Metaph. 986a15-26) - naquela época estudavam as oposiçóes, as mais abstratas, tendo passado da oposição mais antiga entre par e ímpar correspondentes a limitado e ilimitado ( $\pi \dot{\varepsilon} \rho \alpha \varsigma$ e ä́rııрov), a um conjunto de dez oposiçóes. Nada desabona uma possível tentativa de Parmênides buscar uma oposição (a qual era feita também por negação, como nos evidencia a expressão verbal da oposição entre $\pi \dot{\varepsilon} \rho \alpha \varsigma$ e

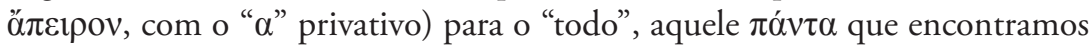

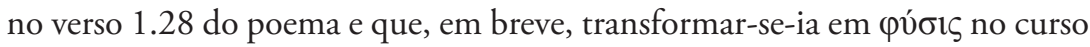
da evoluçáo histórica dos conceitos filosóficos da antiga Grécia.

A meditação do "não-ser" é das mais interessantes a se fazer, na filosofia. Tentar "pensar" o "não-ser" é uma experiência profunda, a qual leva a consideraçóes radicais, não só sobre a existência humana, mas sobre a existência como um todo. Que Parmênides tenha se dedicado a essa meditação é seguro, pois ele o diz indiretamente, em 2.2, quando afirma que os únicos caminhos ao

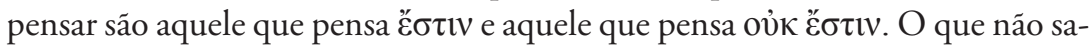
bemos, e não podemos afirmar com certeza, é que tipo de meditação ele reali-

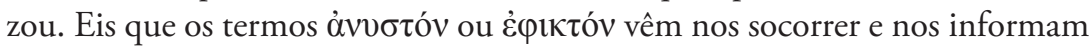
que se trata de uma meditação processual que náo acaba. Descrevi esse processo detalhadamente, em outro trabalho (GALGANO, 2010) e o repetirei aqui brevemente. Pensar o não-ser significa pensar concretamente a negação do ser concreto (do mundo sensível ou inteligível) de cada ser. Para tornar mais claro o processo, pode-se começar negando a existência de um ente, depois daquilo 
que o rodeia, depois do planeta, depois do universo (sensível e inteligível, atual e possível) e depois do mundo como um todo, enfim, do todo.

O problema principal dessa meditação é exatamente pensar se o sujeito pertence ou não ao todo. Quando se pensa a negação do todo, permanece ainda o sujeito pensante, que pensa o todo como se o olhasse de um ponto virtual externo a ele. E quando se tenta incluir o sujeito pensante, de duas uma, 1) ou o sujeito, acreditando pensar a si próprio dentro do todo, reaparece externamente ${ }^{22}$, ou 2) o sujeito cognitivo desaparece e com ele qualquer noção cognitiva de "não-ser". Podemos assegurar claramente que o processo de

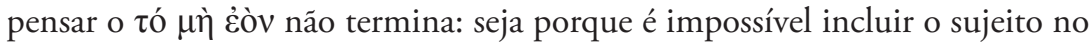
todo, pois ele sempre reaparece a cada tentativa, seja porque o processo, quando inclui o sujeito no todo, interrompe-se, sendo assim impossível completar a negação do todo. Não podemos saber se o modelo meditativo de Parmênides foi exatamente este, mas não me parece haver nada em desabono, ${ }^{23}$

Entretanto, qual é a importância de não se poder pensar a negação de

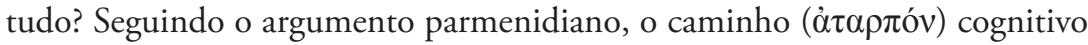

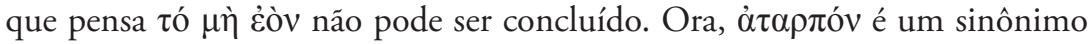

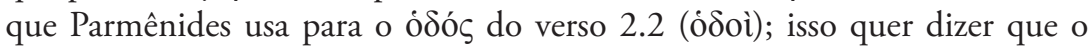
segundo caminho de inquérito pode ser iniciado, mas não pode ser levado a termo. Porém, se não pode ser levado a termo, por que é identificado como caminho? Por que não é excluído já de início, quando a deusa, ao invés de anunciar os únicos (mồnai, plural) caminhos, não anuncia um único caminho? A resposta a essa pergunta torna clara a estranha afirmação de que o caminho do pensar, do segundo hemistíquio do verso 5, é necessário que per-

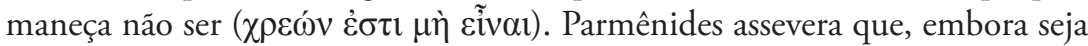
um caminho que jamais pode ser completado, ele, ao mesmo tempo não pode ser eliminado, continua a pertencer aos (dois) únicos caminhos de inquérito, ele é necessário.

\footnotetext{
${ }^{22}$ Se penso na aniquilaçấo de tudo, incluindo a mim mesmo, terei que pensar a mim mesmo aniquilado, contudo esse pensar, gerando esse novo pensamento, gera um novo sujeito cognitivo pensante; se aniquilo esse novo pensamento, terei um novo sujeito cognitivo que pensa essa nova aniquilaçáo e assim por diante ad infinitum.

${ }^{23}$ Não quero garantir que Parmênides estreie uma filosofia do sujeito, embora isso não possa ser excluído a priori, já que os embrióes de uma tal filosofia aparecerão em breve, com Sócrates. Acredito que se deve pensar mais no sujeito como o atleta campeão das Olimpíadas, ou seja, aquele capaz de cumprir (ou não) certas proezas, como fica extraordinariamente evidenciado no paradoxo de Zenão, cuja metáfora da filosofia (e do filósofo) como tartaruga mostra que o pensar filosófico é capaz de proezas maiores do que as proezas do próprio Aquiles, tidas como insuperáveis pela cultura da época.
} 
Vamos de novo reconstruir essa parte do argumento com esse novo elemento: os únicos caminhos de inquéritos são:

1) por um lado, o caminho ao pensar que [versos 3 e 4] $e$

2) por outro lado, o caminho ao pensar que [" $\mathrm{C}$ " (verso 5, primeiro hemistíquio)] e que é necessário (que seja) não-ser.

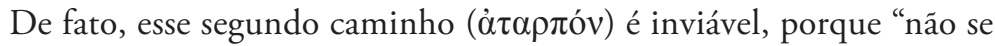

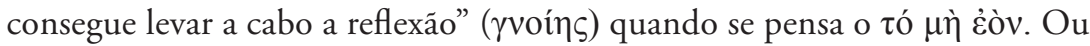
seja, fica muito clara a equação entre o segundo caminho (v. 5) e a reflexão sobre o não ser ( $\tau$ ó $\mu$ ì દ̇òv). Finalmente, o segundo hemistíquio do v. 5 diz que esse é o caminho ao pensar que é necessário que seja $\mu$ हĩv $\tilde{u}_{1}$, o qual,

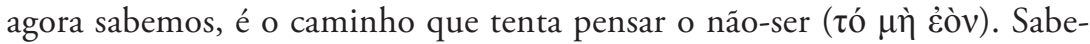

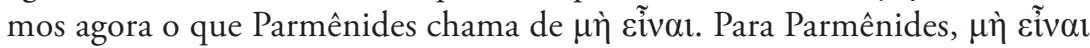
é a estrutura do pensamento, quando tenta inexorável e malogradamente

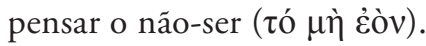

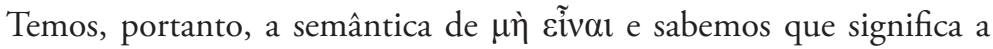
impossibilidade de pensar o náo-ser. Com esse dado, podemos reconstruir o

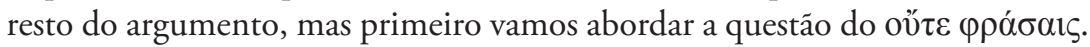
A premissa principal é o pano de fundo da pesquisa parmenidiana, a qual está em busca do discurso confiável, como a deusa diz claramente, no encerramento do fragmento 8 (talvez ecoando simetricamente alguma parte perdida do

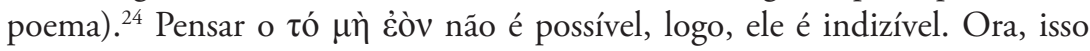
significa, nem mais nem menos, que dizer que o que é impossível é contra o sentido do dizer. É indizível, não porque não se sabe do que se trata, como querem muitos autores que fazem a leitura meramente epistemológica. ${ }^{25} \mathrm{E}$ indizível, porque dizer o "não-ser" significa fazer uma promessa que jamais se cumprirá; ao se dizer "não-ser", parece que a expressão aponta algo possível, ou seja, a negação do ser; e, de fato, quem está desavisado assim acredita. Mas a expressão "não-ser" quer referir-se a algo que jamais será cumprido: que o

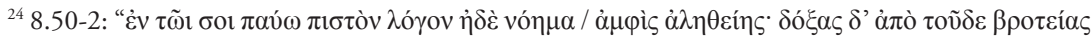

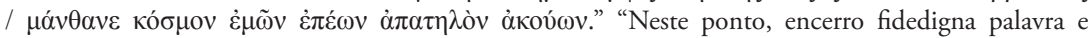
pensamento sobre a verdade; e opiniōes mortais a partir daqui aprende, a ordem enganadora de minhas palavras ouvindo." (CAVALCANTE DE SOUZA, 1978).

${ }^{25}$ Trata-se da leitura epistemológico-predicamental: se não sei a cor de um objeto (porque a cor não é, não está acessível ao meu conhecimento), não posso falar da cor do objeto.
} 
ser seja negado. Esta é exatamente a noção expressa pelas palavras de Platão: jamais prevalecerá que não entes sejam. ${ }^{26}$

A expressão $\mu$ ทे દĩv $\alpha 1$ representa essa impossibilidade de pensamento e, portanto, é um dizer impossível, o que se opóe radicalmente à própria noção de dizer, a qualquer significar, enquanto discurso confiável, do mundo e da sua

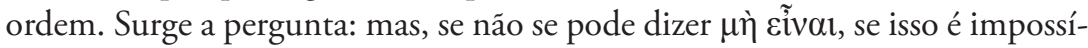
vel, não há uma flagrante contradição na deusa, já que ela própria diz e constrói um argumento sobre o dizer $\mu$ ì cĩvoul? A objeção seria válida, se a deusa dissesse o que é impossível de dizer, ou seja, se ela praticasse a impossibilidade. Todavia, a deusa não diz o impossível, a deusa aponta para o impossível, indica o impossível, pois ela diz que existem a "noção de impossibilidade do pensar" e a "noção de impossibilidade do dizer". Em outras palavras, a deusa diz qual é o limite do pensar e qual é o limite do dizer. Além desse limite, o pensamento não pode ir, porque é impossível, e também o dizer não pode ir, porque é impossível. A impossível região, para além desse limite, não é admitida pelo dizer, é contra o dizer, é contraditória.

A expressão $\mu$ ท̀ عĩvol, em Parmênides, é exatamente a palavra que expressa o processo mental que nós chamamos contradição e que ele primeiro

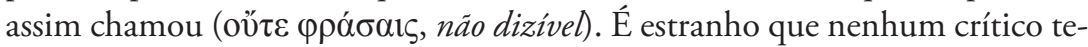
nha percebido isso claramente. Todos afirmam que o princípio de náo contradição está implicado em Parmênides, assim como os outros princípios lógicos, pois os argumentos presentes no poema são desenvolvidos segundo a não contradição, porém, o princípio não é enunciado. Alguns, como Cordero, veem

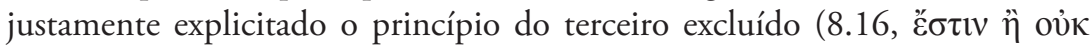
Ě $\tau \tau \imath$ ), mas ninguém quis ver claramente que não só a noção como também

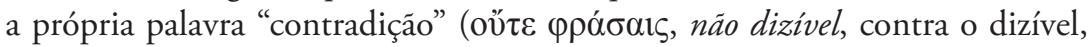
contra a dicção) está explicitada no poema. Penso que a razão fundamental para que acontecesse esse lapsus tenha que ser procurada na grande atenção dada ao "ser" e na pouca dada ao "não-ser". Como observaremos mais adiante, por causa desse lapsus, eu penso que náo se conseguiu entender plenamente a estrutura do fragmento 2, o qual simplesmente não apresenta um silogismo disjuntivo nem nenhuma contradição entre o caminho do "ser" e o caminho do "não-ser". Parmênides assevera, justamente, que a expressão "não-ser" é contraditória; o "não-ser" não pode ser dito, porque "não-ser" é contraditó-

\footnotetext{
${ }^{26}$ As duas expressốes têm inversão de predicado e negação, no entanto, a noção permanece a mesma: que os entes náo sejam (perecimento, no fr. 8) e que os não entes sejam (nascimento, no fr. 8). A noção é o trânsito entre ser e não ser.
} 
rio e a expressão "não-ser" indica tão somente uma impossibilidade concreta, aquela de que se realize o impossível.

Vamos voltar ao nosso argumento e à questão que deixamos em

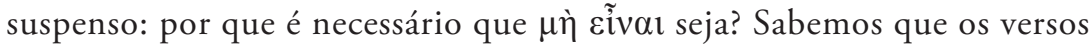

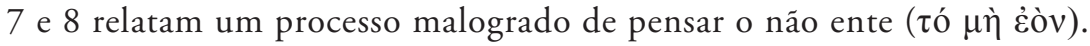
Uso agora a palavra ente, porque se justifica uma diferenciação, embora tanto "ente" quanto "ser" indiquem expressóes gerais e não individuais. "Ente" vem, por conseguinte, a significar o ente concreto, aquele que

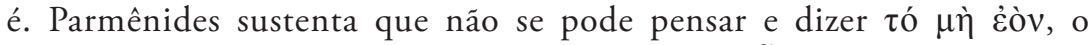
"não ente". Esse processo recebe o nome de $\mu$ ทे عĩvaı, "não-ser"; a esse processo nós chamamos contradição. ${ }^{27}$ Então, a indicação é esta: há um

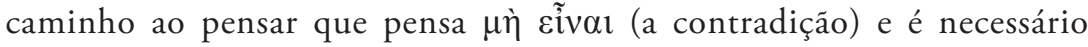
que assim seja, porque (vou repetir três vezes de forma diferente ${ }^{28}$ para significar a mesma coisa):
1) se não houvesse a contradiçáo,
2) se não se tem a noção de contradiçáo,
3) se não se sabe o que é contradição,

cai-se no discurso contraditório, o que impede o inquérito confiável. É ne-

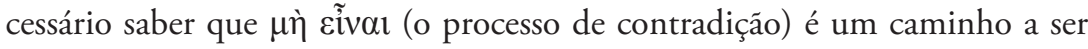
evitado, porque cria pensamentos e discursos contraditórios.

Vejamos de novo nosso fragmento com os elementos esclarecidos até aqui:

os únicos caminhos de inquérito a pensar são,

por um lado, que [... versos 3 e 4...]

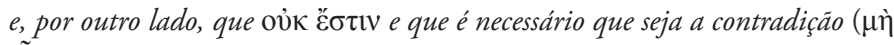
عĩval),

a qual é um caminho não crivel,

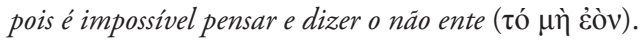

\footnotetext{
${ }^{27}$ Mesmo para nós, a contradição é um processo, porque indica a posição de algo em contraposição com mais algo; isso significa que esses dois algos têm que ser relacionados, para que haja contradiçáo, do contrário, algo e mais algo podem conviver sem contraditoriedade. Contudo, esse assunto está fora de tema e requer muitas outras providências para o bom discernimento.

28 Repito buscando clareza, pois nossas construçōes comuns de linguagem, nesses assuntos, costumam "patinar".
} 


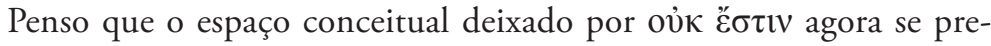
encha quase que por si: há um caminho de inquérito ao pensar que "não é" $e$ que é necessário que se considere contraditório, porque é caminho que náo leva a lugar nenhum.

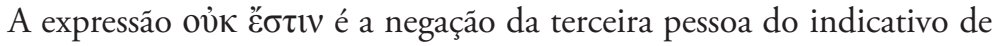

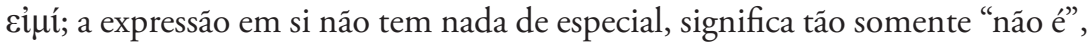
restando em aberto o problema da ausência de sujeito. Mas agora sabemos o argumento complexo que está na raiz da expressão e, a meu ver, não faz muito sentido a questâo de buscar um sujeito ou um objeto, para definir se é usado de forma transitiva ou intransitiva, se expressa existência ou predicação, e as muitas combinações que podem ser montadas a partir da equivocidade do uso de cỉuí. No entanto, o âmbito semântico foi evidenciado e está claro e além do mais tem o testemunho de Platão a confirmar: o campo semântico da negação

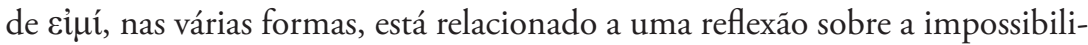
dade dessa negação. Obviamente, para dizer que algo é impossível, de alguma forma tenho que indicar essa impossibilidade com alguma expressão. Assim, se digo "triângulo quadrado", aponto para uma impossibilidade, já que, por definição, a essência do triângulo exclui a essência do quadrado; logo, a expressão "triângulo quadrado" não significa aquilo que parece prometer, ou seja, não significa uma figura geométrica especial que é ao mesmo tempo triângulo e quadrado; dizer "triângulo quadrado" é dizer algo "indizível", "não dizível" (na medida em que o dizível quer expressar sentido), "que nega o dizível”, "que é contra o dizível”, que é contraditório.

A semântica do "não ser" é fortíssima e está muito além das sutilezas gramaticais morfológicas e sintáticas, e estas simplesmente não afetam aquela. $\mathrm{O}$ assunto tratado é tão forte que ultrapassa qualquer forma linguística, a ponto de que esse assunto, a ordem do ser e do não-ser no mundo, é responsável pela determinação da lei da linguagem e não vice-versa, como bem entendeu Platão, no Sofista, onde a teoria da predicação surge em função de uma reflexão sobre a ordem das leis básicas do mundo. Com efeito, o approach linguístico ao poema pode proceder até certo ponto; dali em diante, o poema é francamente filosófico e a chave linguística não é suficiente para o acesso. Isso quer dizer que, com a chave linguística, não se abre a porta da questão filosófica do poema. Se a questáo é que "jamais o não ser pode se tornar ser", como (aproximadamente com essas palavras) argumenta Platão, citando Parmênides, en-

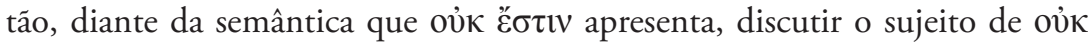

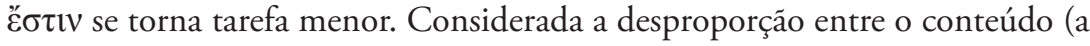


semântica) e o recipiente (a palavra), entre o significado e o significante, não é

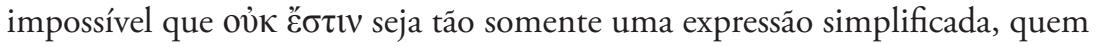
sabe, até mesmo uma simplificação didática, pois o conteúdo do conceito está expresso e justificado depois, nos versos 7 e 8 .

O caminho de pensar que não é e de pensar que é necessário não ser é o caminho que afirma a necessidade de que a noção de não-ser permaneça estável. A contradição tem que permanecer e ser identificada como tal, pois é a única maneira de evitar que ela entre no pensamento e no discurso. Se o "não-ser" não for considerado contraditório, a contradição invade e domina o caminho de inquérito, o qual deixa de possuir $\pi i ́ \sigma \tau 1 \varsigma \grave{\alpha} \lambda \eta \theta \hat{\eta} \varsigma$ (1.30). Assim,

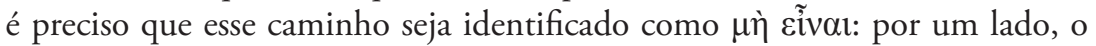

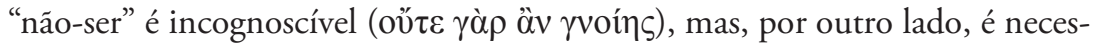
sário que se saiba que ele é incognoscível. Saber do incognoscível garante o conhecimento $^{29}$, pois, de fato, ao não se identificar o "não-ser", cai-se no risco de pensar que "ser" e "não-ser" são o mesmo e não o mesmo, como Parmêni-

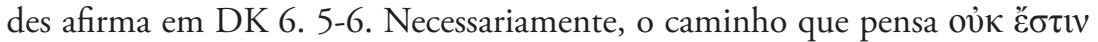
leva ao processo de contradição ( $\mu$ ì عĩval), e a não conclusão do caminho

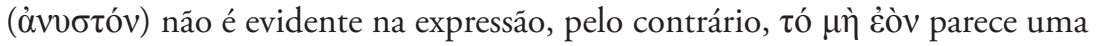
negação comum, como qualquer outra, porém, não o é, por isso é um saber destinado ao sábio e não aos mortais, porque é um saber fruto de uma reflexão.

\subsection{DE VOLTA AOS VERSOS 3 E 4}

Penso que podemos agora voltar ao verso 2.3 , ao nosso segundo he-

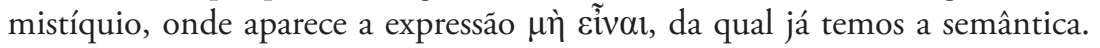
Podemos entâo reconstruir: "os únicos caminhos de inquérito a pensar são,

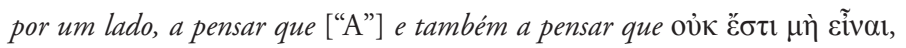
este é caminho de persuasão pois verdade acompanha, e

por outro lado, a pensar que "não é" e também a pensar que é necessariamente um percurso de pensamento contraditório, porque é um caminho "impossivel" ( $\pi \alpha v \alpha \pi \varepsilon v \theta \varepsilon \dot{\varepsilon} \alpha)$, pois o pensamento do "não ente" não pode ser completado.

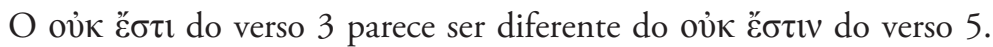
Enquanto, no 5, ele é quase que o nome do caminho (talvez uma simplificação didática), no 3, parece significar simplesmente "não é", em sentido comum

${ }^{29}$ Está aqui uma semente do socratismo. 
predicativo. De fato, esse é o caminho da persuasão e, portanto, é o caminho do pensamento náo-contraditório. Ali a persuasão era impossível pela contradição, aqui é possível pela não-contradição. Sabemos que a expressão $\mu$ ì Eĩval é a expressão da contradição suprema, de sorte que a não-contradição é

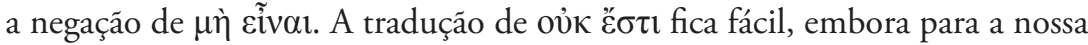

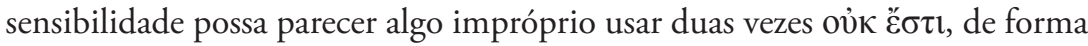
não perfeitamente unívoca a dois versos de distância. Logo, para o segundo hemistíquio do v. 3, mantenho esta tradução, "não é", em parte ambígua para nossas exigências, mas que soa perfeitamente harmônica com o discurso parmenidiano: [...] ao pensar que ["A"] e que não é "contradição" ( $\mu$ ̀̀ Eĩval).

Acredito, por fim, que podemos abordar facilmente o ह̌ $\sigma \tau \iota v$ do verso 3, que tanto fez e faz penar os estudiosos de Parmênides. Aqui, de novo, a grandeza da questáo cosmológica envolvida - a coerência e/ou a contraditoriedade do real - simplesmente torna táo minúscula a questáo do sujeito de

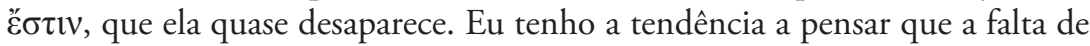
sujeito seja uma simplificação didática ${ }^{30}$, cuja irregularidade linguística ajuda na memorização. ${ }^{31}$ Todavia, afinal, tomo partido e entro também no quarto grupo daqueles listados por Cordero: o sujeito deve ser extraído do predicado isolado, pois ह̌ $\sigma \tau \imath$ produz o sujeito. ${ }^{32}$ De qualquer forma, o sentido filosófico é preciso: há um caminho de inquérito ao pensar, que é aquele que pensa o “é”, esse mesmo caminho é aquele ao pensar que não é (e não pode $\operatorname{ser}^{33}$ ) "contradição". Depois, há um outro caminho, aquele ao pensar que "não é”, que é o caminho ao pensar que leva necessariamente à contradição. $\mathrm{O}$ primeiro é o

\footnotetext{
${ }^{30}$ Segundo o relato platônico, no diálogo Parmênides, Zenão, acompanhado de seu mestre, foi para as Panateneias com a finalidade de defender a filosofia de seu mestre, esclarecendo com seu livro, repleto de paradoxos, as ideias parmenidianas. Isso sugere que o poema não expunha articuladamente a filosofia de Parmênides, mas que constituísse um pró-memória, com as ideias em sua forma essencial, depois elaboradas nas aulas pessoais (KURFESS, 2012).

${ }^{31}$ É extraordinário como essa simplificação didática continue ativa, por um lado, distorcendo, entretanto, por outro, mantendo viva a mensagem parmenidiana, em todas as escolas de ensino médio onde se estuda filosofia, vox populi, Parmênides é o filósofo que disse: "O que é é e o que não é não é". Por outro lado, o estrangeiro de Eleia, no Sofista, lembra outro verso e náo este.

32 Essa questão, não aprofundada aqui, não possui relevância filosófica no argumento apresentado; pode ter relevância, se se considera o tipo de reflexão, ou seja, se se discute a "experiência" do não-ser e, principalmente, a experiência concreta de Parmênides, que talvez esteja ligada a práticas de incubação. Nesse caso, a dimensão reflexiva adentra a dimensão onírica, a qual possui outra sintaxe e onde um

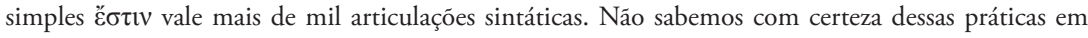
Eleia, contudo, esse sentido pré-sintático não está descartado; inclusive alguns estudiosos, entre os

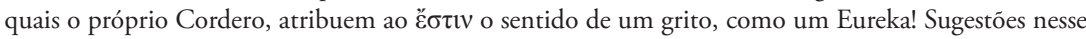
sentido se encontram na minha dissertaçâo sobre Melisso (GALGANO, 2010).
}

${ }^{33} \mathrm{~A}$ interpretação modal é também perfeitamente coerente aqui. 
caminho que estabelece o discurso coerente (persuasivo) e o segundo não leva a lugar nenhum e deve ser evitado. Mas, para que se saiba o que deve ser evitado, é preciso que se conheça a impossibilidade do segundo caminho. A fim de que se possa seguir o primeiro caminho, é necessário saber que existe um outro, sempre à espreita, o qual parece oferecer a verdade, mas que náo oferece uma verdade confiável, que leva necessariamente à contradição de pensamento e de expressão linguística.

\section{O MÉTODO DA NÁO-CONTRADIÇÃo}

Parmênides, provavelmente a partir de sugestôes pitagóricas, medita sobre a oposição ao que existe e assim descobre o "não-ser". Descobre que "não ser”, ou seja, negar o ser, negar o que há, é de todo impossível (não é possível completamente). Entende então que o "não-ser", essa impossibilidade, é algo que a mente pensa, julgando que esse pensamento leva por um caminho, mas que, na verdade, ele descobre, leva por outro caminho, aquele que nunca chega a lugar nenhum. Esse caminho que leva para lugar nenhum é o caminho dos mortais, os quais confundem ser e não ser. No entanto, o sábio deve saber distinguir: por um lado, o caminho do "é", que é o caminho do discurso não contraditório, e, por outro lado, o caminho do "não é", que é o caminho do discurso que é tornado vão pela contradição.

Parmênides descobre a contradição (pela meditação sobre o não-ser) e percebe que ela é motivo de descaminho no discurso sobre o mundo. Assim, finalmente ele anuncia que a contradição deve ser evitada. A esse enunciado nós chamamos de princípio de não-contradição, que aqui é aquele na versão de Parmênides (depois, a partir de Platão e Aristóteles, haverá outras versôes). Parmênides trabalha em âmbito cosmológico e sua preocupação - como os de seus colegas na época - é com o mundo, com a totalidade das coisas, com os $\pi \alpha ́ v \tau \alpha$ de seu proêmio (1.28). Nesse âmbito cosmológico, descobre que há um princípio do mundo pelo qual se dá uma impossibilidade: a contradição. A contradição é um princípio, porque o que há ( $\pi \alpha ́ v \tau \alpha)$, enquanto todo, escapa à negação total. Eis que a contradição é princípio tanto quanto a não-contradição, porque é a contradiçãa que permite a não-contradiçãa. Sem a noção de contradição se anda com sentidos incertos, como os mortais.

O valor dessa afirmação é historicamente inabalável, porque Parmênides, partindo de um discurso sobre o mundo como que visto de fora por um observador (como Anaximandro via o mundo olhando seu pinax - cf. ROS- 
SETTI, 2013), alcança um discurso que inclui o observador enquanto observador, estreando assim antes de tudo um discurso sobre os entes (ontologia), todos os entes, incluindo os entes de pensamento (veja-se o famoso fragmento 3 , onde se lê que pensar e ser são o mesmo). Para ele, o sábio não é mais aquele que sabe só sobre as coisas externas - como o antigo xamã, cuja figura individual se dissolve na mera intermediação com o divino -, porém, é também aquele que consegue pensar sobre as coisas externas, ou seja, aquele que tem um domínio cognitivo sobre os pensamentos de inquérito e, portanto, sabe sobre si mesmo. Assim, o sábio deve pensar por própria conta e julgar pelo novo

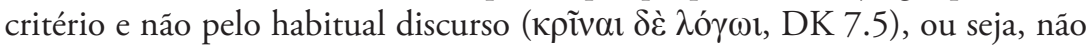
deve julgar pelo discurso, mas julgar $o$ discurso, porque agora o discurso, enriquecido de uma lei universal (a lei das $\alpha \rho \chi \alpha ́$ ह̌ medida de juízo. Parmênides amplia o mundo, acrescentando ao mundo físico os mundos do pensamento e da linguagem. Eis porque as $\alpha \rho \chi \alpha ́$ de Parmênides, sendo duas, permanecem duas justamente eliminado uma delas, deixando alguns críticos enlouquecidos na discussão sobre o monismo ou o dualismo; de acordo com Parmênides, o mundo é um, todavia, os sentidos nos enganam, não na pluralidade das coisas, mas no argumento a respeito da pluralidade das coisas e principalmente - aspecto que ele discute explicitamente - a respeito do devir das coisas. Há um princípio que não pode ser eliminado, a contradição, o qual é um princípio de erro humano: quando se elimina, quando se desconsidera, quando se faz de conta que não existe, a contradição se instaura; quando o princípio é levado em conta, a contradição pode ser evitada.

É uma conceituação esdrúxula para nós também, porque temos que ter (a noção de) a contradição para eliminar a contradição, temos que saber o que é contradição para que possamos perceber quando o discurso é contraditório. Esses conceitos são misteriosos até agora e são estranhas criaturas de nossas mentes. Por exemplo, a noção de "impossível”, obviamente (isto é, para a nossa pragmática) não se refere a nada de concreto, no entanto, temos essa noçáo e a usamos com o máximo proveito; outro exemplo, a noção de "infinito", noção que não se refere a algo pragmaticamente concreto, mas que usamos igualmente com máximo proveito. $\mathrm{O}$ mesmo deve ser dito da noção de contradição ou da noção de nada absoluto, que usamos pragmaticamente, com maior ou menor proveito.

Parmênides encontra esse caminho e o expõe. É um caminho assombroso, anti-intuitivo, mas incontestável. Dessa forma, não é de estranhar se a solução platônica é a eliminaçáo física da noção de nada absoluto (o par- 
ricídio) com sucessivo "adeus" ${ }^{34}$, achando de tê-lo ultrapassado. Mas o nada absoluto, enquanto noção contraditória, permanece. Assim como permanece a explicação defeituosa do devir, o qual, assim como o conhecemos, uma passagem do nada ao ser, no nascimento, e do ser ao nada, no perecimento, está mal explicado. Daqui por diante, os comentários filosóficos possíveis são inúmeros, por conseguinte, paro meu estudo neste ponto e proponho a versão do fragmento 2, segundo a conceituação apresentada até aqui, alterando de pouco a excelente versão básica de Cavalcante de Souza:

Pois bem, eu te direi, e tu recebe a palavra que ouviste,

os únicos caminhos de inquérito que são a pensar:

o primeiro, que é e, portanto, que não é (o caminho da) contradição,

de persuasão é o caminho (pois à verdade acompanha);

o outro, que não é e, portanto, que é necessariamente (o caminho da) contradição,

este então, eu te digo, é atalho de todo incrível;

pois nem conhecerias o que não é (pois não é exequível), nem o dirias...

GALGANO, N. S. Non-being in Parmenides of Elea. Trans/form/ação, Marília, v. 41, n. 2, p. 9-36, Abr./Jun., 2018.

\begin{abstract}
AвSTRACT: In fragment DK 28 B 2 of his poem, Parmenides presents his method for distinguishing true persuasion from the lack of true persuasion. His famous proposal of these two ways of thinking form a complex statement of a system that intends to guarantee the veracity of statements in order to obtain reliable discourse, the only discourse capable of true persuasion. The present paper shows that the central role in Parmenidian argumentation is attributed to non-being, a notion derived from a reflection on the impossibility of the negation of being. Thus the whole fragment is interpreted in terms of this central notion. We show that Parmenides discovered the impossibility of negation, which we now call 'contradiction', and that he articulated the means for avoiding contradiction in thought and discourse, a rule which today we call the principle of non-contradiction. The study presented here is a detailed investigation of the notion of non-being in the DK 28 B 2 fragment, and includes a new translation of it.
\end{abstract}

KeYwords: Parmenides. Non-being. Non-contradiction. Eleatism. Parricide.

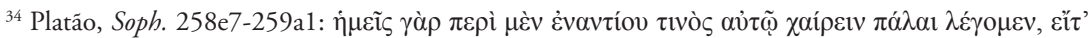

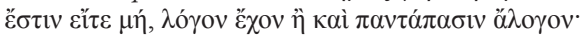




\section{REFERÊNCIAS}

BARNES, J. The presocratic philosophers. Londres: Routledge, 1982.

BONIFAZI, A. Problematizing early IE syndetic coordination: ancient Greek "and" from Homer to Thucydides. In: CONGRESSO "SYNTATIC CHANGE AND SYNTACTIC RECONSTRUCTION: NEW PERSPECTIVES”. Abstract de paper. Zurich, 2012.

CAVALCANTE DE SOUZA, J. (Dir.). Os pré-socráticos. São Paulo: Abril Cultural, 1978. CORDERO, N. L. La déesse de Parménide, maitresse de philosophie. In: MATTÉI, J. F. (Éd.). La naissance de la raison en Grèce. Paris: P.U.F., 1990. p. 207-214.

. Siendo, se es: la tesis de Parménides. Buenos Aires: Biblos, 2005.

COXON, A. H. The fragments of Parmenides. Revised and expanded edition. Las Vegas: Parmenides Publishing, 2009.

DENNISTON, J. D. The greek particle. 2. ed. Oxford: OUP, 1954.

GALGANO, N. A transgressão de Melisso. 2010. 180 f. Dissertação (Mestrado em Filosofia) - FFLCH-USP, São Paulo, 2010.

. A verdade tem um coração intrépido? em Una mirada actual a filosofia griega, Madrid: SIFG, 2012.

. Amēkhaniê in Parmenides DK 28 B 6.5. Journal of Ancient Philosophy (Engl. Ed.), v. 10, n. 2, p.1-12, 2016. Disponível em: www.revistas.usp.br/filosofiaantiga. Acesso em: 10 mar. 2018.

. Parmenides as psychologist - part I: fragments DK 1 and 2. Archai, n. 19, jan/ abr., p. 167-205, 2017a.

. Parmenides as psychologist - part II: fragments DK 6 and 7. Archai, n. 20, maio/ago., p. 39-76, $2017 \mathrm{~b}$.

. I precetti della dea. Non essere e contraddizione in Parmenide di Elea. Bologna: Diogenes Multimedia, 2017c.

GALLOP, D. Parmenides of Elea: fragments. Toronto: University of Toronto Press, 1984.

HUMBERT, J. Syntaxe greque 2. ed. Paris: Klincksieck, 1954.

KAHN, C. H. The verb 'be' in ancient greek. 2. ed. Indianapolis: Hackett Publishing, 2003.

. Essays on Being. Oxford: OUP, 2009.

KURFESS, C. Restoring Parmenides poem: essays toward a new arrangement of the fragments based on a reassessment of the original sources. 2012. Tese (Doutorado) University of Pittsburg, Pittsburg, 2012.

MANSFELD, J. Die Offenbarung des Parmenideliche Welt. Assen: Van Gorcum, 1964. 
MEIJER, P. A. Parmenides beyond the gates. Amsterdam: J. C. Gieben, 1997.

ROSSETTI, L. La structure du poéme de Parménide. Philosophie Antique, Paris, n. 10, p. $187-226,2010$.

. L'ideazione del pinax, "medial innovation" di Anassimandro. In: LEÃO, D.; CORNELLI, G.; PEIXOTO, M. C. (Ed.). Dos homens e suas ideias: estudos sobre as Vidas de Diógenes Laércio. Coimbra: Imprensa da Universidade de Coimbra, 2013. p. 89-100.

SMYTH, H. W. Greek grammar, Cambridge: Harvard University Press, 1956.

TARÁN, L. Parmenides. Princeton: Princeton University Press, 1965. 